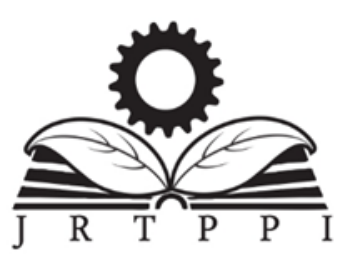

Vol. 10 No. 1 (2019) 29-37

Jurnal Riset

Teknologi Pencegahan Pencemaran Industri

Kementerian

Perindustrian

REPUBLIK INDONESIA

Journal homepage: ejournal.kemenperin.go.id/jrtppi

\title{
Enhanced Performance of Multi-Stage Anaerobic Digestion of Tofu Wastewater: Role of Recirculation
}

\author{
Hanny Vistanty ${ }^{1 *}$ and Rizal Awaludin Malik ${ }^{1}$ \\ ${ }^{1}$ Balai Besar Teknologi Pencegahan Pencemaran Industri, Jl. Ki Mangunsarkoro No. 6 Semarang 50136, Central Java, Indonesia
}

\section{A R T I C L E I N F O}

Article history:

Received 18 March 2019

Received in revised form 10 May 2019

Accepted 10 May 2019

Available online 27 May 2019

\section{Keywords:}

Recirculation

Anaerobic

Tofu Wastewater

COD

Ammonia

\begin{abstract}
A B S T R A C T
Continuous three-stage anaerobic reactors with recirculation system were employed to treat real tofu wastewater. The system consists of 3 reactors connected in series and effluent of the last reactor was partly returned as feed of the first reactor along with fresh wastewater. The recirculation systems were conducted on four variations of recirculation ratio $(\mathrm{RR}) \mathrm{s}$ of $0,1.0,1.3$, and 1.5 to evaluate the influence of recirculation on stability and performance of anaerobic system. Results showed that recirculation improved the performance of anaerobic digestion. COD were fluctuated without recirculation and gradually decreased to 373 and $298 \mathrm{mg} / \mathrm{L}$ at RR 1.3 and 1.5, respectively. Likewise, $\mathrm{pH}$ value was dropped to 6.5 at RR 0 , and started to increase to approximately 8.0 upon employing recirculation. In addition, the system also showed excellent toleration against rise in ammonia loading, with effluent ammonia approximately $4.678 \mathrm{mg} / \mathrm{L}$. The findings showed that the system employed had an excellent efficiency and stability in treating tofu wastewater.
\end{abstract}

\section{INTRODUCTION}

Soybean curd (tofu) is a popular traditional food in Asian countries, especially Indonesia, produced by small and medium-sized enterprises around the country. Currently, wastewater generated from those industries is discharged without proper treatment, producing mainly bad odour and inflicting high risk to the environment, as it contains high $\mathrm{BOD}$ and $\mathrm{COD}$ representing high content of organic pollutants. Odour is commonly the main element raising complaint from the surrounding society as the industry is usually located in a densely populated housing area. The process itself requires a large volume of water as it involves soaking and washing processes of soybean and almost all of processed water ends up as wastewater containing sugar, fat, protein, carbohydrate and starch, thus it needs to be processed before discharged into main stream (Belén, Sánchez, Hernández, Auleda, \& Raventós, 2012). The main component of tofu (soybean) is dominated by high protein, organic and nitrogen concentration and easily acidified, that was treated satisfactorily by anaerobic digestion before (Zeng, Hou, \& Cui, 2011).

Anaerobic digestion is not only efficient and appropriate to treat organic pollutants, but it also can be used to produce energy in the form of biogas and electricity (Abbasi et al., 2016; Abdel-Shafy \& Mansour, 2014; Cavinato, Bolzonella, Fatone, Cecchi, \& Pavan, 2011; Y. Chen et al., 2016; Ratanatamskul \& Siritiewsri, 2015). However, high content of suspended solids in the wastewater may inflict another problem due to low

${ }^{*}$ Correspondence author. Tel.: +6224 8316315

E-mail: hannyvistantybbtppi@gmail.com (H. Vistanty)

doi: https://10.21771/jrtppi.2019.v10.no.1.p1-10

2503-5010/2087-0965 (C) 2018 Jurnal Riset Teknologi Pencegahan Pencemaran Industri-BBTPPI (JRTPPI-BBTPPI).

This is an open acces article under the CC BY-NC-SA license (https://creativecommons.org/licenses/by-nc-sa/4.0/).

Accreditation number: (LIPI) 756/Akred/P2MI-LIPI/08/2016 
biodegradability of protein (Mottet et al., 2009). Previous researches have investigated various technologies to improve solubility as a way to increase biodegradability of wastewater through application of various pre-treatments as they reported that higher solubility leads to higher degradation (Domingues et al., 2015; Malik et al., 2016; Masse, Massé, \& Kennedy, 2003; Mukimin, Vistanty, Zen, Purwanto, \& Wicaksono, 2018).

Anaerobic system may be improved by enhancing the hydrolysis and acidification stages by several methods, such as recirculation. Many studies propose the solution to this limitation by modifying the anaerobic reactor with a circulation system. High circulation stream will contribute to a better mass transfer and higher contact between granular sludge and wastewater, higher organic loading rate (OLR) and pollutant removal efficiency, and better resistance to shock loading (Wang, Xu, Yan, \& Yu, 2014). $\mathrm{Li}$ et al reported an improvement in substrate hydrolysis leading into biogas production enhancement with thermochemical pre-treatment (Li, Champagne, \& Anderson, 2015). While another study concluded that the use of bio equalization pre-treatment was able to reduce TSS significantly as an effect of substrate hydrolysis (Mukimin et al., 2018).

So far, previous researches have focused the utilization of tofu wastewater for biohydrogen production using Rhodobacter sphaeroides (Zheng, Wang, \& Kang, 2010; Zhu, Suzuki, Tsygankov, Asada, \& Miyake, 1999) while the application of multi-circulation of UASB has not been well studied. In this work, the performance of a modified recirculation UASB was investigated for tofu wastewater treatment. The effect of recirculation ratio on ammonia content was also studied.

\section{METHODS}

\subsection{Experimental setup}

The experiment was performed using three laboratory-scale anaerobic reactors, R1, R2, and R3, and arranged in a series connection. The reactors were all cylindrical and made of acrylic with a working volume of $5.3 \mathrm{~L}$, as used in our previous research (Vistanty, Mukimin,
\& Handayani, 2015). The anaerobic digestions were arranged in 3 different systems. A system without recirculation was used as control (system control). The other system configurations consisted of three-stage anaerobic reactors connected in series, with recirculation ratio $(R R)$ of 1, 1.3 and 1.5. The effectivity of each system would be evaluated in comparison. Peristaltic pump (Cole Parmer Masterflex L/S 7518-62) was connected to intake point to adjust the influent flow rate. The outlet point was on the top side of reactor and equipped with a partition to prevent the sludge washout along with the effluent. RR was commonly defined as the ratio of returned water to that of the original inlet of reactor.

\subsection{Substrate and inoculum}

Soybean curd or tofu wastewater used in this study was collected from one of small industry in Central Java, Indonesia. It was used as it is, without any pre-treatment. As the wastewater was highly organic and tend to be acid, calcium oxide was added to prevent reactor failure. The characteristics of tofu wastewater was listed in Table 1.

Table 1. Characteristics of tofu wastewater

\begin{tabular}{lcc}
\hline Parameter & Value & unit \\
\hline $\mathrm{pH}$ & 5.5 & \\
TCOD & $9133-6162$ & $\mathrm{mg} / \mathrm{L}$ \\
BOD & 4300 & $\mathrm{mg} / \mathrm{L}$ \\
VFA & 573 & $\mathrm{mg} / \mathrm{L}$ \\
ammonia & 8.949 & $\mathrm{mg} / \mathrm{L}$ \\
TSS & 673 & $\mathrm{mg} / \mathrm{L}$ \\
\hline
\end{tabular}

The seed sludge inoculated in all reactors was an acclimated anaerobic bacterium taken from another laboratory-scale UASB reactor that had been used previously.

The characteristics of seed sludge in terms of total solids, volatile solids, fixed solids, and $\mathrm{pH}$ are summarized in Table 2, as mentioned in our previous research (Vistanty et al., 2015). 
Table 2. Characteristics of seed sludge

\begin{tabular}{ll}
\hline Parameter & Value \\
\hline TS & $14.45 \%$ \\
VS & $63.02 \%$ \\
FS & $36.98 \%$ \\
pH & 7 \\
\hline
\end{tabular}

\subsection{Procedure}

As initial start-up, reactor was adapted to wastewater by feeding diluted wastewater $(50 \%)$ in a closed circulation system, which meant that the effluent was pumped back to as the inlet of reactor. This step was conducted to acclimate the bacteria after being in its stationary phase. After 5 days, the reactor was operated continuously with fresh wastewater as feed and a hydraulic retention time (HRT) of $24 \mathrm{~h}$. The recirculation was applied after $4 \mathrm{~d}$ of operation in continuous mode. Process configuration is shown in Fig. 1.

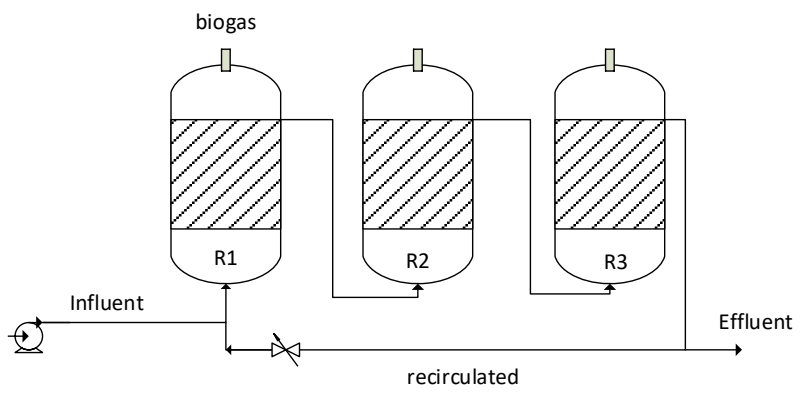

Figure 1. Schematic reactor configuration applied in the treatment of tofu wastewater

\subsection{Materials}

Wastewater used in this study was collected from the raw effluent of one of tofu industry. All the reagents were of analytical grade and were used without any treatment or purification.

\subsection{Analytical methods}

The effluent of each reactor was taken and measured daily in terms of $\mathrm{pH}$, chemical oxygen demands, and ammonia. $\mathrm{pH}$ value was measured using a $\mathrm{pH}$ meter, while
$\mathrm{COD}$ and $\mathrm{NH}_{3}-\mathrm{N}$ were measured according to the Standard Methods for the Examination of Water and Wastewater (E.W. Rice, R.B. Baird, A.D. Eaton, 2017). COD measurement was carried out using Hanna HI 839800 reactor. $\mathrm{pH}$ adjustment was carried out using calcium oxide.

\section{RESULT AND DISCUSSION}

\subsection{Initial start-up}

At the stage of initial start-up, reactor was operated in a closed circulated system with an influent COD of 5000 $\mathrm{mg} / \mathrm{L}$ and $\mathrm{pH}$ adjusted to 8.3. During this stage, the outlet of reactor was then contained and pumped back to the influent part of reactor. At the end of start-up (fifth day), COD removal reached $81 \%$, COD effluent was about 900 $\mathrm{mg} / \mathrm{L}$ and $\mathrm{pH}$ of 8 .

\subsection{Anaerobic performance without recirculation ( $R R O$ )}

After start-up was completed, the reactor was then operated continuously without recirculation for 11 days. The changes in COD and $\mathrm{pH}$ of each reactor are displayed in Fig. 1. The COD effluent of each reactors at RR 0 was fluctuate and even sharply increased from $1157 \mathrm{mg} / \mathrm{L}$ to $3941 \mathrm{mg} / \mathrm{L}$, and the effluent was observed turbid. Simultaneously, $\mathrm{pH}$ was also decreased to 6.5 , making it the optimum pH for acidogenic (Mutombo, 2004) and indicating generation of organic acid in the reactor. The increase of COD effluent might be attributed to minimum contact between wastewater and anaerobic sludge, due to the deposition of sludge on the base of reactor, leading to limited degradation zone. The deposition of sludge was possible due to low hydraulic flow. This phenomenon was also mentioned in another study (Y. Zhang, Ma, Quan, Jing, \& Dai, 2009).

\subsection{Effect of recirculation ratio on performance of reactor}

As COD is considered as an important effluent quality index of wastewater discharge standard in Indonesia, it serves as a key parameter to evaluate the performance of system applied in this study. The effect of recirculation ratio was investigated at RR 1.0, 1.3 and 1.5, as shown in Fig. 2. 
The results show that all three reactors were detected unstable at RR 1, in which COD increased and fluctuated from 649,968 , and $982 \mathrm{mg} / \mathrm{L}$ to 2152,2178 , and 1898 $\mathrm{mg} / \mathrm{L}$ at reactor 1, 2 and 3, respectively. The effluent COD was slowly decreased at RR 1.3 and reached approximately 571,315 , and $373 \mathrm{mg} / \mathrm{L}$ at reactor 1, 2 and 3, respectively. Simultaneously, when RR increased to 1.5 , the performance of reactors was maintained stable, which implies that the performance of system was improved as $\mathrm{RR}$ increased. The average COD were about 381,321 and $298 \mathrm{mg} / \mathrm{L}$ at reactor 1, 2 and 3, respectively. This may have occurred because hydraulic circulation facilitated microorganisms to function in a more expanded space and increase contact between substrate and sludge (Y. Zhang et al., 2009). These findings demonstrated that anaerobic digestion with recirculation system showed satisfactory degradation performance.

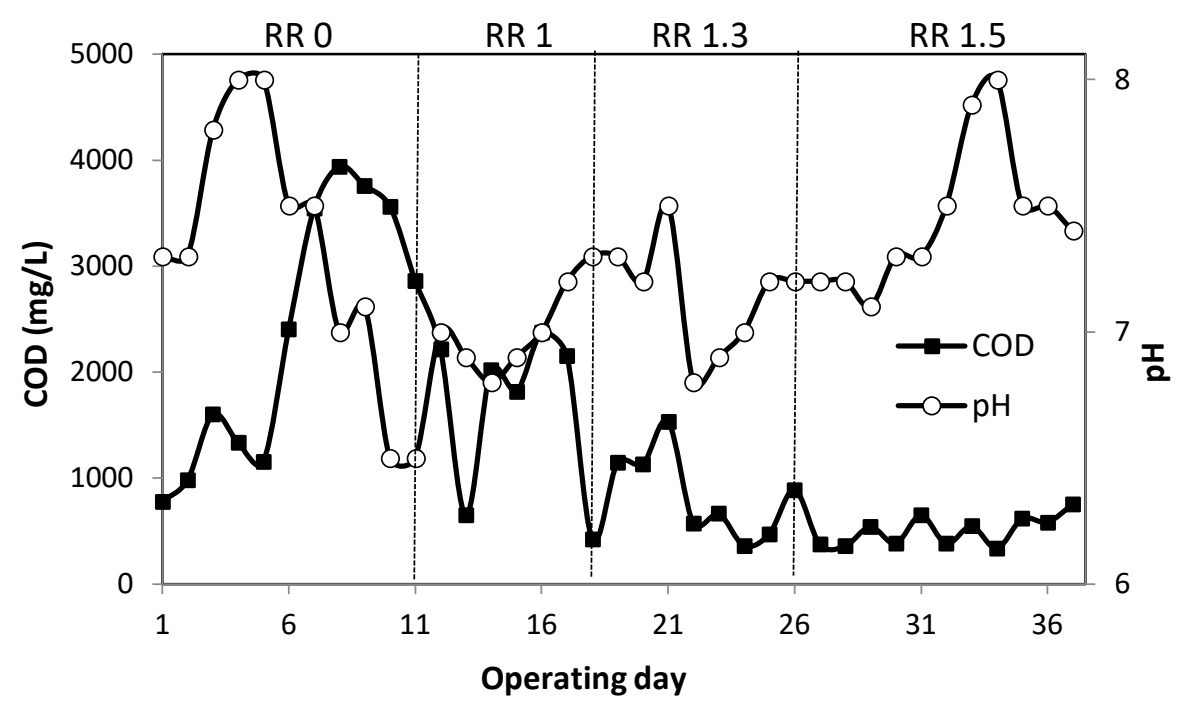

(a)

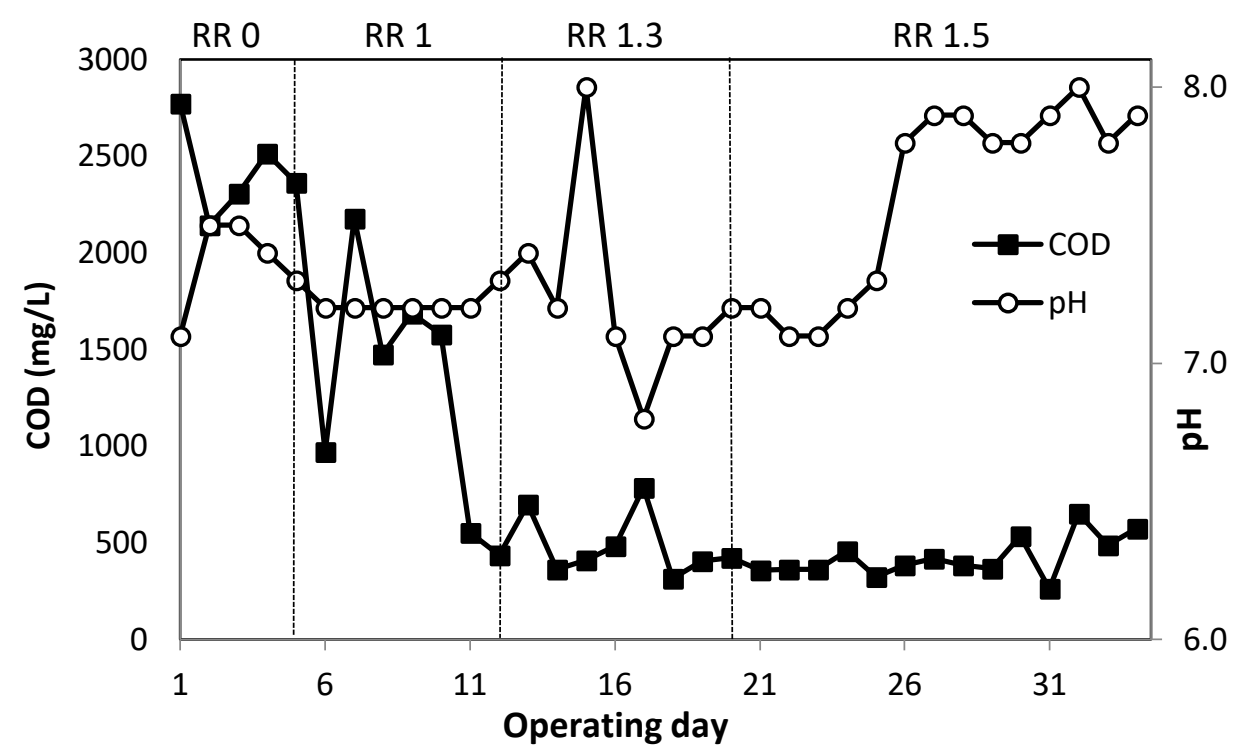

(b) 


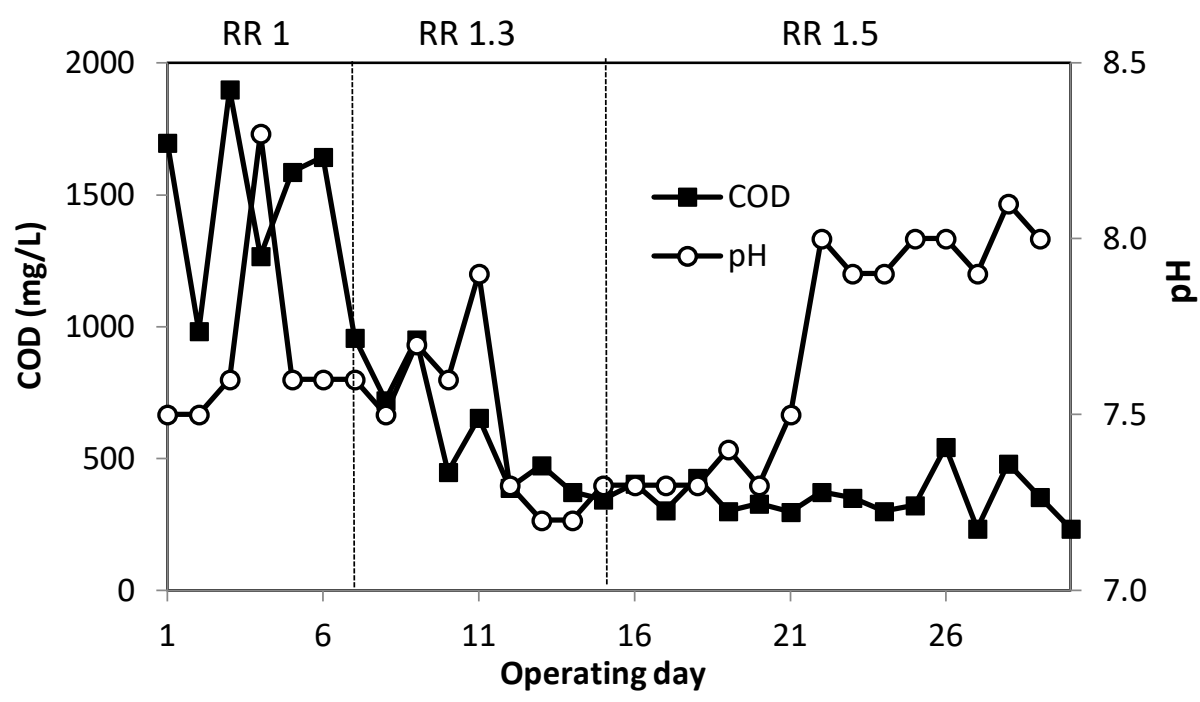

(c)

Figure 2. Changes of $\mathrm{pH}$ and COD effluent of (a) R1, (b) R2, and (c) R3 during operational

At $\mathrm{RR} 1$, the $\mathrm{pH}$ in all reactors were gradually increased to $7.0,7.2$ and 7.5 in reactor 1,2 , and 3 , respectively. The $\mathrm{pH}$ value was slightly decreased to $6.8,6.8$ and 7.2 at RR 1.3 in reactor 1, 2 and 3, respectively, possibly due to the sudden increased loading of influent ammonia and accumulation of ammonia as shown in Fig. 3. The $\mathrm{pH}$ value was gradually increased at RR 1.5 and reached 8.0, 8.0 and 8.1 in reactor 1,2 and 3 , respectively, when the anaerobic system was able to survive the ammonia shock loading. The $\mathrm{pH}$ value stabilization of $\mathrm{pH}$ was achieved upon employing recirculation possibly due to the circulated methanogenic bacteria and alkalinity from R3 that avoid the anaerobic digestion from VFA overload. Moreover, $\mathrm{pH}$ value ascended dramatically to 8.0 at RR 1.5 and stabilized at around 7.5, indicating the methanation step has occurred, as the optimum $\mathrm{pH}$ value for methanogens was about 6.5 to 7.5. Another study also mentioned that recirculation system would release trapped biogas in the bottom of the reactor and prevent inhibition of anaerobic digestion by $\mathrm{CO}_{2}$ saturation and increase $\mathrm{pH}$ value $(\mathrm{Y}$. Zhang et al., 2009). Furthermore, recirculation can also improve the buffer capability to resist various shock loadings by circulating the alkalinity back to the system (Wu et al., 2012).

\subsection{Ammonia removal}

Amino acids are the result of hydrolysis, acid production, and methanation of protein in an anaerobic degradation, as protein is easily degraded under anaerobic condition (Park \& Kim, 2015). The amino acids may be degraded into VFA, ammonia and $\mathrm{CO}_{2}$, due to the disengagement of amino groups through deamination. Ammonia may act as inhibitor both for acidogenic and methanogens bacteria in anaerobic digester (R. Zhang et al., 2007). Shock loading of ammonia concentration may lead to digester failure caused by inhibition of bacteria activity to breakdown the protein content in the substrate. Ammonia can also emerge from imperfect anaerobic breakdown of protein. However, inhibition of anaerobic bacteria activity could be avoided by conducting bacteria acclimation with feeding out the bacteria with ammonia at gradually increasing concentration (Yenigün \& Demirel, 2013).

Considering the great role and impact of ammonia on stability of anaerobic digester, we also evaluate the trend of ammonia contents and the effect of recirculation ratio (RR) on it. The effect of recirculation ratio and initial ammonia concentration on effluent ammonia is depicted in Fig. 3. It was observed that the initial ammonia of 8.949 $\mathrm{mg} / \mathrm{L}$ was not influencing effluent ammonia, in which ammonia detected approximately $1.692-0.597 \mathrm{mg} / \mathrm{L}$ on 
three reactors, and the system was still stable. It shows that the anaerobic microorganisms were able to tolerate the amount of ammonia present in the system. It was also reported that, at low concentration, ammonia is beneficial to anaerobic digester, however, at high concentration it could act as inhibitor to several methanogenic bacteria (Sprott \& Patel, 1986).

The stability of anaerobic system can be disturbed when methanogenic bacteria do not grow well, and will lead to increasing VFA concentration indicated by decreased $\mathrm{pH}$ value due to VFA accumulation. Ammonia shock loading in reactor 1 occurred at day 21 when the influent was 35 $\mathrm{mg} / \mathrm{l}$ ammonia and $\mathrm{pH}$ dropped from 7.5 to 6.8 after $24 \mathrm{~h}$. Likewise, $\mathrm{pH}$ value on reactor 2 decreased from 8.0 to 7,1 and 6.8 after 1 and $2 \mathrm{~d}$, respectively. It was possible due to the drastic increase of ammonia content in reactor 2 at $103.98 \mathrm{mg} / \mathrm{l}$ which was higher than other reactors. While reactor 3 demonstrated similar conditions, with decreased $\mathrm{pH}$ value from 7.9 to 7.3 on day 11 . These findings indicated that VFA accumulated in the system because it was not converted by methanogenic bacteria due to disturbance to the activity of methanogenic bacteria in the presence of increased ammonia concentration.

Fig. 3. showed that the hydrolysis of protein in tofu wastewater has occurred, indicated by increased concentration of ammonia, as it exhibited the deamination process of amino acids. Reactor 1 was able to recover from ammonia shock and showed a decrease to $18.237 \mathrm{mg} / \mathrm{L}$ on fifth day, while $\mathrm{R} 3$ reach the lowest ammonia concentration on sixth day of operation at $4.678 \mathrm{mg} / \mathrm{L}$. Reactor 2 was observed to be the most difficult to cope with elevated initial ammonia concentration, and reach the lowest value at $35.493 \mathrm{mg} / \mathrm{L}$. It may be concluded that R1 was the most benefited from recirculation system and more resistant to high ammonia concentration than the other reactors. The benefit of effluent recirculation in alleviating the inhibition of excess VFA and maintain process stability was also reported by another study (Zuo, Wu, Qi, \& Dong, 2015). It is also reasonable to propose that reactor 2 was the dominant place where the deamination process occurred and the products were subsequently degraded in reactor 3 , while the undegraded ammonia was partly recirculated to reactor 1 . However initial ammonia content in this study served no drastic inhibition on the anaerobic digestion, since it was still less than $1,500 \mathrm{mg} / \mathrm{L}$ (Park \& Kim, 2015). It was consistent with the system performance in terms of COD reduction and $\mathrm{pH}$ value (Fig.2). Low COD effluent indicated system stability while $\mathrm{pH}$ value of 8 showed no VFA accumulated and hindering the system.

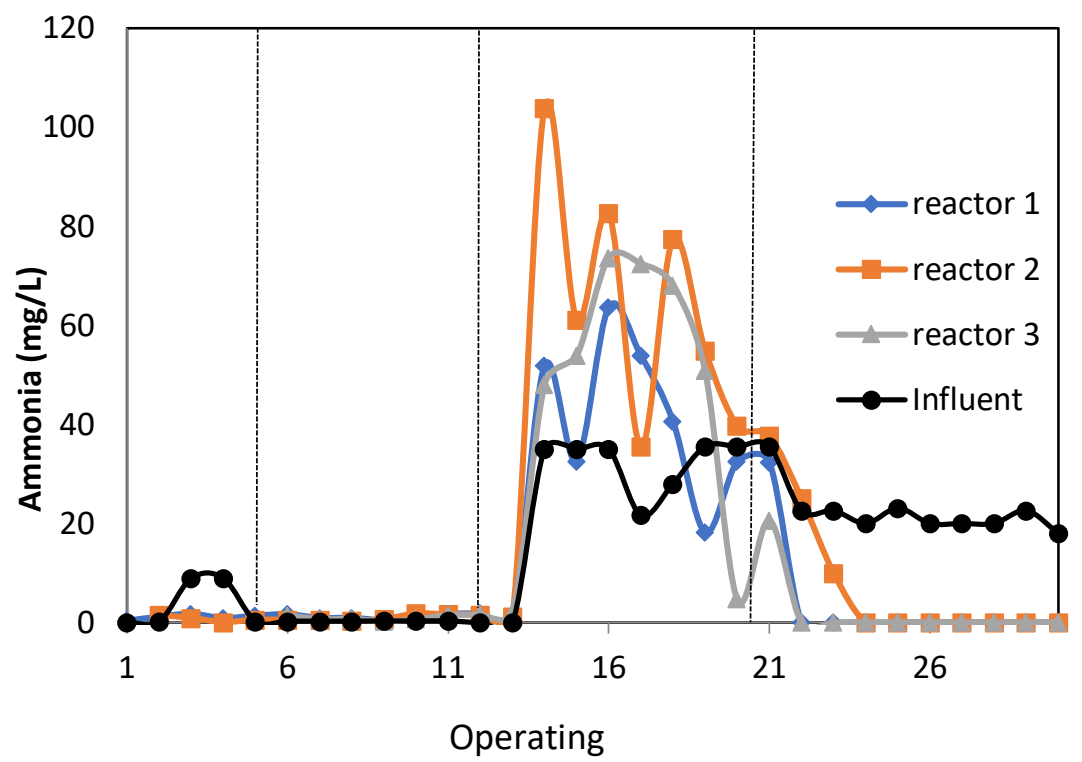

Figure 3. Profile of ammonia concentration on each reactor 


\section{CONCLUSION}

A multi-stage anaerobic digestion with recirculation was employed to treat tofu wastewater in this study. After initial start-up, the system was operated continuously without recirculation ( $R R \quad 0)$ and showed unstable performance in terms of COD and $\mathrm{pH}$. Afterwards, the recirculation system was applied and showed an outstanding impact towards COD and $\mathrm{pH}$ value, in which both parameters were stabilized. High loading of ammonia was fed to the anaerobic digestion and cause a drastic increase of ammonia in all reactors. However, the system was able to recover from ammonia shock due to the benefit of effluent recirculation in avoiding VFA overload and maintain the stability of process.

\section{ACKNOWLEDGMENT}

This work was supported by the Center of Industrial Pollution Prevention Technology and the laboratory of research and development.

\section{REFERENCES}

Abbasi, U., Jin, W., Pervez, A., Bhatti, Z. A., Tariq, M., Shaheen, S., ... Mahmood, Q. (2016). Anaerobic microbial fuel cell treating combined industrial wastewater: Correlation of electricity generation with pollutants. Bioresource Technology, 200, 1-7. https://doi.org/10.1016/j.biortech.2015.09.088

Abdel-Shafy, H. I., \& Mansour, M. S. M. (2014). Biogas production as affected by heavy metals in the anaerobic digestion of sludge. Egyptian Journal of Petroleum, 23(4), 409-417. https://doi.org/10.1016/j.ejpe.2014.09.009

Belén, F., Sánchez, J., Hernández, E., Auleda, J. M., \& Raventós, M. (2012). One option for the management of wastewater from tofu production: Freeze concentration in a falling-film system. Journal of Food Engineering, 110(3), 364-373. https://doi.org/10.1016/j.jfoodeng.2011.12.036
Cavinato, C., Bolzonella, D., Fatone, F., Cecchi, F., \& Pavan, P. (2011). Optimization of two-phase thermophilic anaerobic digestion of biowaste for hydrogen and methane production through reject water recirculation. Bioresource Technology, 102(18), 8605-8611. https://doi.org/10.1016/j.biortech.2011.03.084

Chen, Y., Zhang, F., Wang, T., Shen, N., Yu, Z. W., \& Zeng, R. J. (2016). Hydraulic retention time affects stable acetate production from tofu processing wastewater in extreme-thermophilic $(70 \mathrm{oC})$ mixed culture fermentation. Bioresource Technology, 216, $722-728$. https://doi.org/10.1016/j.biortech.2016.06.015

Domingues, R. F., Sanches, T., Silva, G. S., Bueno, B. E., Ribeiro, R., Kamimura, E. S., Tommaso, G. (2015). Effect of enzymatic pretreatment on the anaerobic digestion of milk fat for biogas production. Food Research International, 73, 26-30. https://doi.org/10.1016/j.foodres.2015.03.027

E.W. Rice, R.B. Baird, A.D. Eaton, editors. (2017). Standard Methods for the Examination of Water and Wastewater. 23rd ed. American Public Health Association, Washingto, DC, USA. https://doi.org/ISBN 9780875532356

Li, C., Champagne, P., \& Anderson, B. C. (2015). Enhanced biogas production from anaerobic codigestion of municipal wastewater treatment sludge and fat, oil and grease (FOG) by a modified twostage thermophilic digester system with selected thermo-chemical pre-treatment. Renewable Energy, 83 , 474-482. https://doi.org/10.1016/j.renene.2015.04.055

Malik, R. A., Vistanty, H., Sartamtomo, Setianingsih, N. I., Crisnaningtyas, F., \& Zen, N. (2016). Wastewater treatment of bakery industry using stripper-activated sludge system. Jurnal Riset Teknologi Pencegahan Pencemaran Industri, 7(2), 89-98.

Masse, L., Massé, D. I., \& Kennedy, K. J. (2003). Effect of hydrolysis pretreatment on fat degradation during anaerobic digestion of slaughterhouse wastewater. 
Process Biochemistry, 38(9), 1365-1372. https://doi.org/10.1016/S0032-9592(03)00020-7

Mottet, A., Steyer, J. P., Déléris, S., Vedrenne, F., Chauzy, J., \& Carrère, H. (2009). Kinetics of thermophilic batch anaerobic digestion of thermal hydrolysed waste activated sludge. Biochemical Engineering Journal, 46(2), 169-175. https://doi.org/10.1016/j.bej.2009.05.003

Mukimin, A., Vistanty, H., Zen, N., Purwanto, A., \& Wicaksono, K. A. (2018). Performance of bioequalization-electrocatalytic integrated method for pollutants removal of hand-drawn batik wastewater. Journal of Water Process Engineering, 21. https://doi.org/10.1016/j.jwpe.2017.12.004

Mutombo, D. T. (2004). Internal circulation reactor: pushing the limits of anaerobic industrial effluents treatment technologies. Proceedings of the 2004 Water Institute of Southern Africa (WISA) Biennial Conference, Cape Town, South Africa., (May), 608616.

Park, S., \& Kim, M. (2015). Effect of ammonia on anaerobic degradation of amino acids. KSCE Journal of Civil Engineering, 1-8. https://doi.org/10.1007/s12205-015-0240-4

Ratanatamskul, C., \& Siritiewsri, T. (2015). A compact onsite UASB-EGSB system for organic and suspended solid digestion and biogas recovery from department store wastewater. International Biodeterioration \& Biodegradation, $\quad 2-8$. https://doi.org/10.1016/j.ibiod.2015.04.002

Sprott, G. D., \& Patel, G. B. (1986). Ammonia toxicity in pure cultures of methanogenic bacteria. Systematic and Applied Microbiology, 7(2-3), 358-363. https://doi.org/10.1016/S0723-2020(86)80034-0

Vistanty, H., Mukimin, A., \& Handayani, I. (2015). Pengolahan air limbah industri karton box dengan metode integrasi upflow anaerobic sludge bed reactor (UASB) dan elektrokoagulasi-flotasi. Journal Riset Teknologi Pencegahan Pencemaran Industri, 6(1), $1-8$.
Wang, J., Xu, W., Yan, J., \& Yu, J. (2014). Study on the flow characteristics and the wastewater treatment performance in modified internal circulation reactor. Chemosphere, 117(1), 631-637. https://doi.org/10.1016/j.chemosphere.2014.09.08 8

Wu, J., Zhang, J. B., Jiang, Y., Cao, Z. P., Poncin, S., \& Li, H. Z. (2012). Impacts of hydrodynamic conditions on sludge digestion in internal circulation anaerobic digester. Process Biochemistry, 47(11), 1627-1632. https://doi.org/10.1016/j.procbio.2012.03.009

Yenigün, O., \& Demirel, B. (2013). Ammonia inhibition in anaerobic digestion: A review. Process Biochemistry, 48(5-6), 901-911. https://doi.org/10.1016/j.procbio.2013.04.012

Zeng, K., Hou, Y., \& Cui, Y. (2011). The research of Square Internal Circulation Anaerobic Reactor to treatmenting soybean protein wastewater, 13291332.

Zhang, R., El-Mashad, H. M., Hartman, K., Wang, F., Liu, G., Choate, C., \& Gamble, P. (2007). Characterization of food waste as feedstock for anaerobic digestion. Bioresource Technology, 98(4), 929-935. https://doi.org/10.1016/J.BIORTECH.2006.02.03 9

Zhang, Y., Ma, Y., Quan, X., Jing, Y., \& Dai, S. (2009). Rapid startup of a hybrid UASB-AFF reactor using bi-circulation. Chemical Engineering Journal, 155(1-2), 266-271. https://doi.org/10.1016/j.cej.2009.08.005

Zheng, G. H., Wang, L., \& Kang, Z. H. (2010). Feasibility of biohydrogen production from tofu wastewater with glutamine auxotrophic mutant of Rhodobacter sphaeroides. Renewable Energy, 35(12), 2910-2913. https://doi.org/10.1016/j.renene.2010.04.030

Zhu, H., Suzuki, T., Tsygankov, A. A., Asada, Y., \& Miyake, J. (1999). Hydrogen production from tofu wastewater by Rhodobacter sphaeroides immobilized in agar gels. International Journal of Hydrogen 
Energy, 24(4), 305-310. https://doi.org/10.1016/ S0360-3199(98)00081-0

Zuo, Z., Wu, S., Qi, X., \& Dong, R. (2015). Performance enhancement of leaf vegetable waste in two-stage anaerobic systems under high organic loading rate: Role of recirculation and hydraulic retention time. Applied Energy, 147(17), 279-286. https://doi.org/10.1016/j.apenergy.2015.03.001 